\title{
Research Towards Sustainable Parking Solutions
}

doi:10.2478/mape-2021-0034

Date of submission to the Editor: 03/2021

Date of acceptance by the Editor: 05/2021

MAPE 2021, volume 4, issue 1, pp. 376-386

Jolanta Baran

ORCID ID: 0000-0003-3144-8257

Silesian University of Technology, Poland

Anna Miklis

ORCID ID: 0000-0002-7118-0972

Silesian University of Technology, Poland

Iwona Żabińska

ORCID ID: 0000-0002-9368-4311

Silesian University of Technology, Poland

\section{INTRODUCTION}

Urban space is characterized by a significant deficit of parking spaces in relation to needs. This raises social, economic, environmental, and urban planning issues (Bukowski et al., 2018; Ślęzok and Łuczak, 2015). They occur at every stage of the life cycle of car parks, but are particularly evident during their use. The above mentioned problems, as well as the continuous increase in the number of vehicles, high land prices, small plots of land, or the costs of building car parks that exceed investors' budgets, make it necessary to look for solutions that, in line with new research directions, take into account all dimensions of sustainable development, as well as the assumptions of the circular economy and the results of the latest research on smart cities and the mobility of the future (Górniak, 2016).

In general, this research is focused on:

- reduction of costs incurred at different stages of the life cycle of a car park,

- Optimisation of the social costs and benefits over the life cycle of a car park,

- reduction of the environmental impact over the life cycle of a car park.

The needs and expectations of interested parties in a life-cycle perspective should be integrated into the research stream (Ferretti, 2016; Mathew et al., 2014) (Fig. 1).

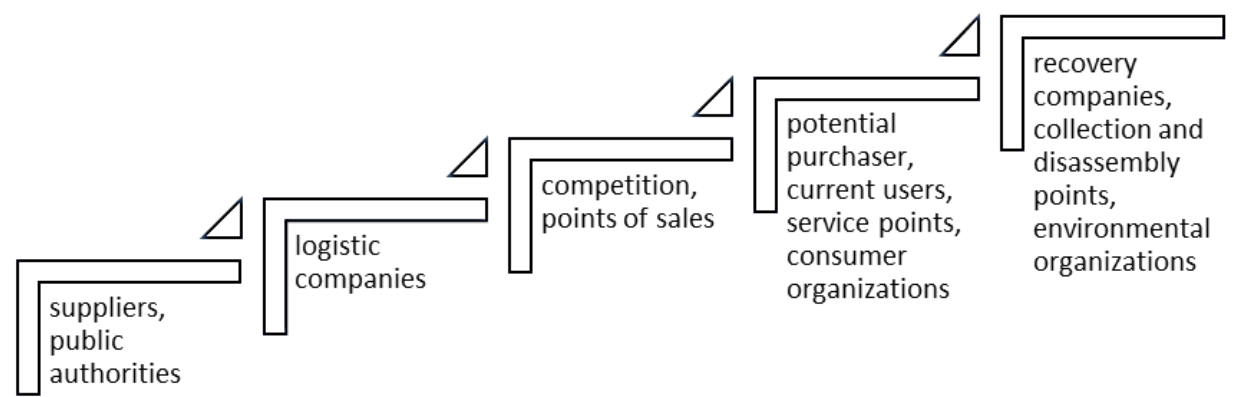

Fig. 1 Interested parties of the external environment in the perspective of the entire product life cycle (from obtaining raw materials to post-consumer waste management) Source: own study based on (Kurczewski and Lewandowska, 2008). 
This article presents the results of a questionnaire survey of car park users and therefore addresses the stage of car park use.

\section{METHODOLOGY OF RESEARCH}

The survey was conducted using the Computer-Assisted Web Interview CAWI technique. Respondents answered a survey questionnaire that was posted on the 'Google Forms' website. The survey was conducted on a sample of $N=172$ persons. The survey questionnaire consists of twelve closed questions and three metric questions. Responses to five questions in the questionnaire were structured using a five-point Likert scale (yes, rather yes, rather not, not, I have no opinion). The remaining questions asked for opinions on specific aspects of parking usage.

\section{DISCUSSING THE RESULTS OF THE QUESTIONNAIRE SURVEY}

The aim of the survey is to identify problems and public expectations regarding parking and the use of different parking solutions. The gender division of the respondents was as follows: $61 \%$ of respondents were women, $39 \%$ were men. $95 \%$ of respondents live in the Silesia region. The age structure of respondents is as follows: $78 \%$ of the respondents were $18-30$ years old, $10 \%$ of the respondents were 31-45 years old and 46-60 years old. People aged 61 and more constitute $2 \%$ of respondents. The opening question of the survey asked how often the respondents travel by car. The biggest number of respondents $49 \%$ - declare daily commuting by car (Fig. 2).

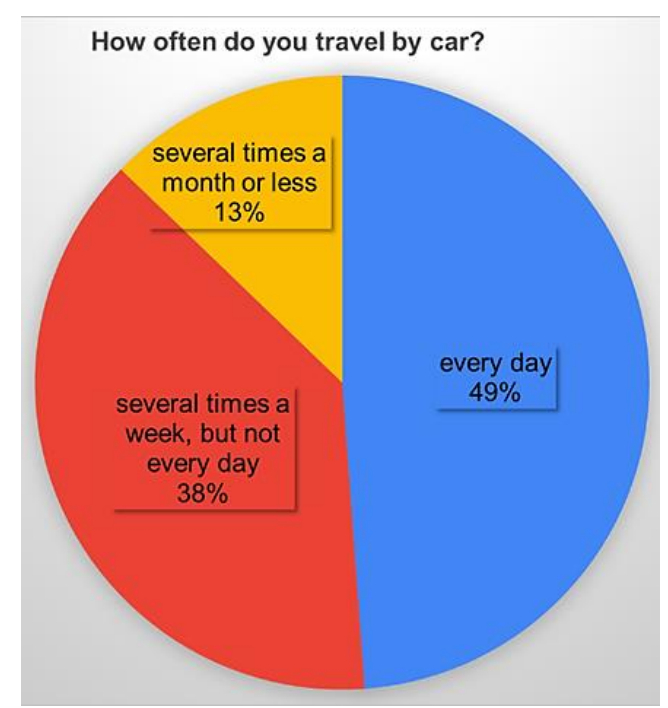

Fig. 2 Frequency of using a car

A large percentage of respondents use a car several times a week $-38 \%$. In the next question (Fig. 3) respondents declared the type of housing in their place of residence. Most respondents - 47\% - live in a house while $43 \%$ live in a block of flats. $6 \%$ of respondents declare they live in a terraced house. 


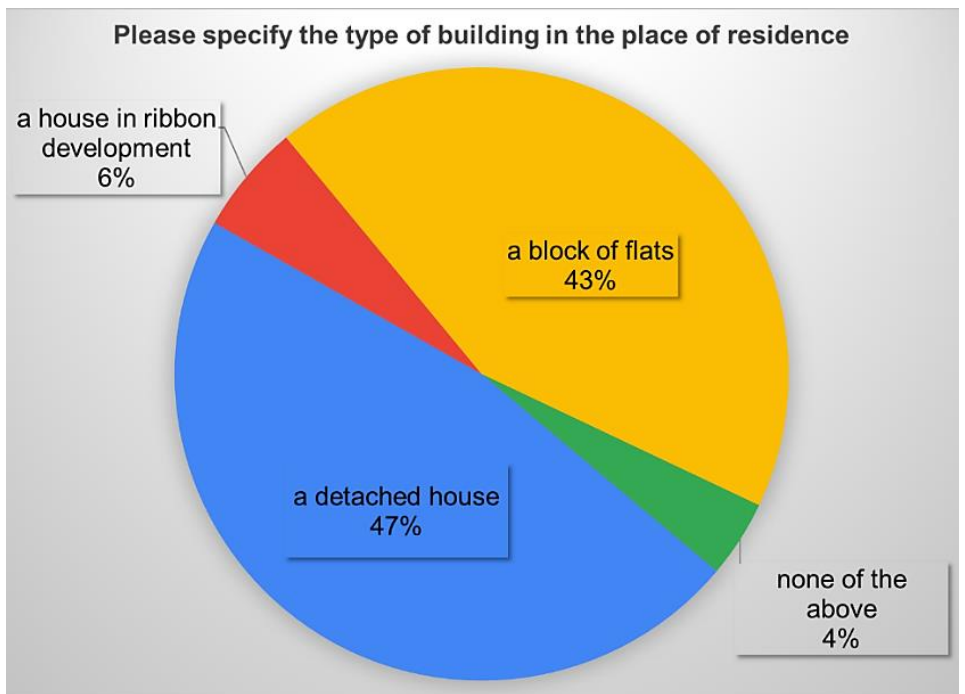

Fig. 3 Type of housing in the place of residence

Respondents expressed their opinion about sufficiency of parking spaces near their homes (Fig. 4).

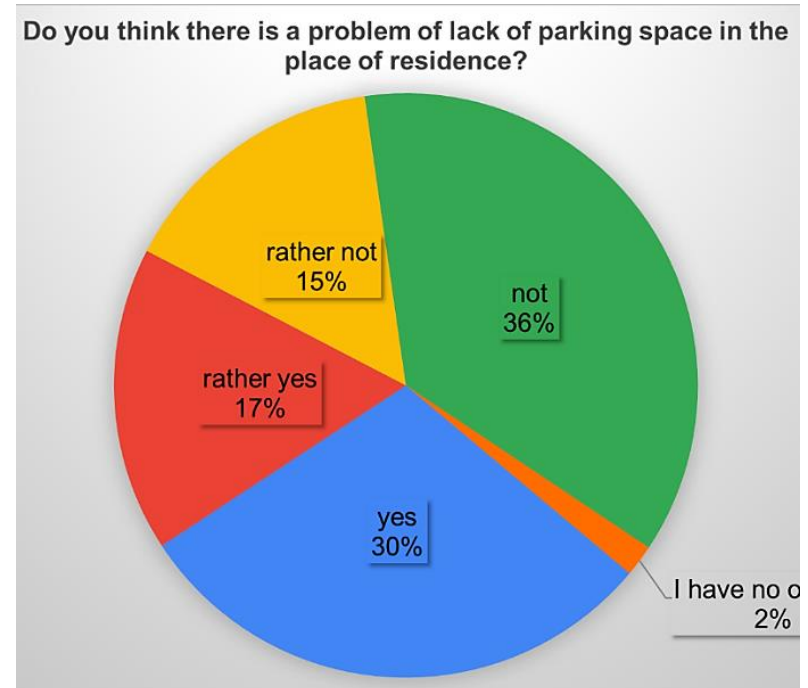

Fig. 4 Sufficiency of parking spaces near the house

The majority, i.e. $36 \%$ declare that this problem does not exist, while $30 \%$ of respondents said that there is a lack of parking spaces at their place of residence. A cross-analysis integrating the answers according to the type of housing in the place of residence (Fig. 5) shows that the problem of parking space deficit and the need for increased parking space occurs mainly according to people living in blocks of flats. The problem doesn't rather exist according to residents of detached houses.

Respondents' assessment of the need for increased parking space is fairly even (Fig. 6). The percentage of those who see such a need is $46 \%$, while $43 \%$ of respondents do not see such a need. Cross-correlation analysis with the declared type of housing in the residence shows that the vast majority of people (60 people) who perceive a need for new parking spaces live in a block of flats. 


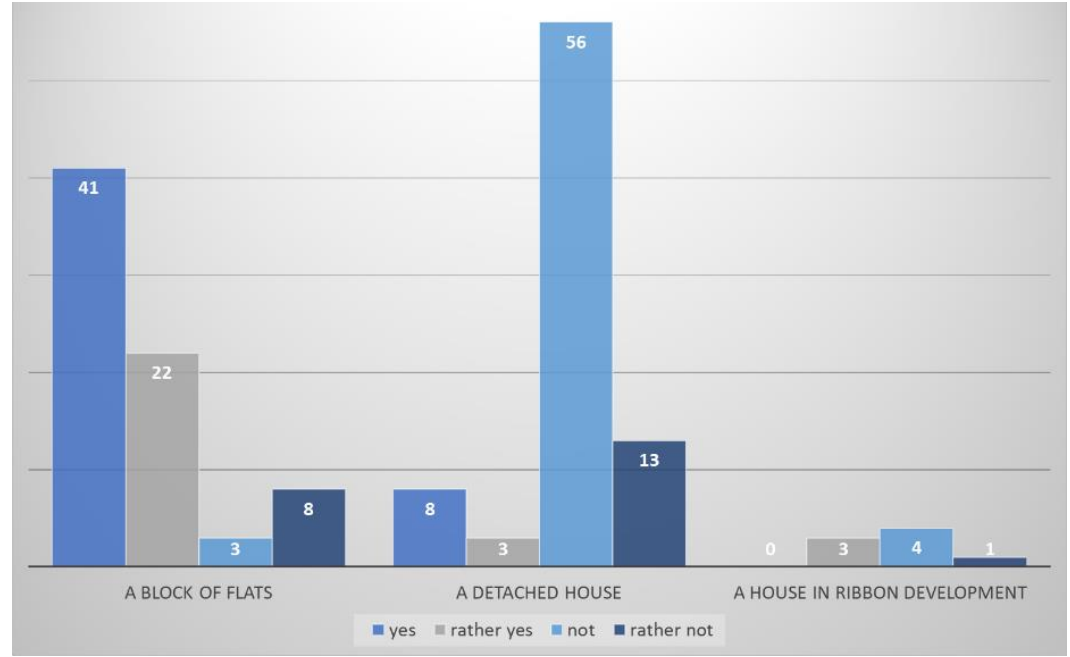

Fig. 5 Sufficiency of parking spaces according to people living in different types of houses (number of people who answered the question "Do you think there is a problem with parking a car at your place of residence?")

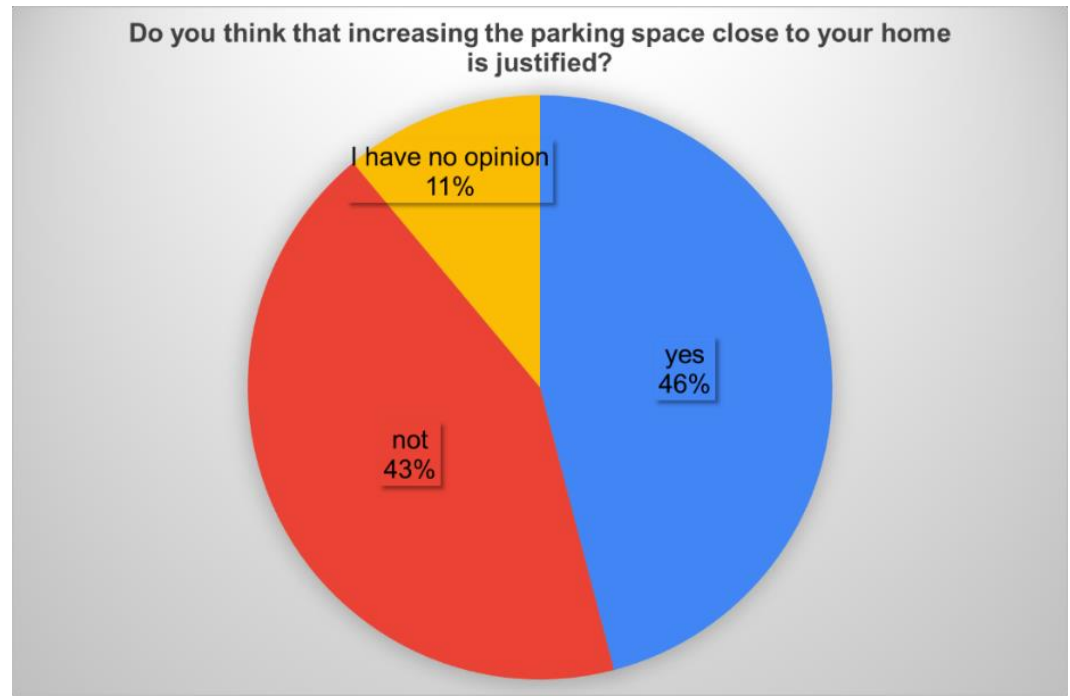

Fig. 6 Assessment of the need for increasing parking space

The number of people living in a detached house who are of a similar opinion is 12 people.

Most respondents (61\%) commute to work by car (Fig. 7). Only 5\% of respondents declare to use public transport only. $24 \%$ of respondents use both public transport and a private car to varying degrees.

The percentage of people commuting by car almost coincides with the percentage of people who see the problem of insufficient parking spaces near their workplace (Fig. 8). Cross-analysis shows that $68 \%$ of car commuters perceive the number of parking spaces at their workplace as insufficient.

The majority of respondents $-59 \%$ - allow a parking distance of up to 5 minutes from their residence (Fig. 9).

These are mainly car commuters (Fig. 10). For $35 \%$ a time up to 10 minutes is acceptable. Relatively few people (6\%) express acceptance for longer distances. 


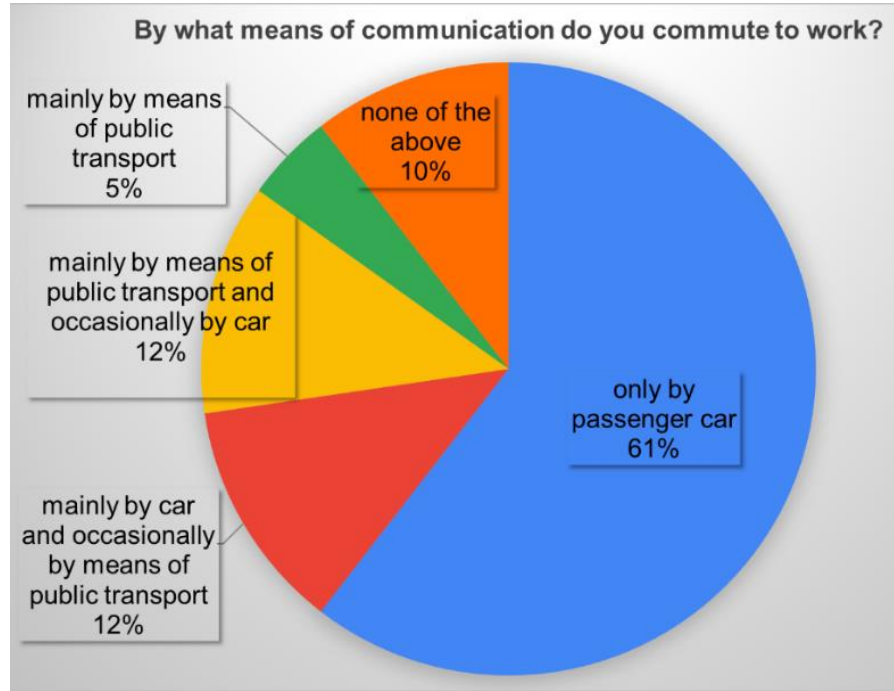

Fig. 7 Means of transport used for commuting

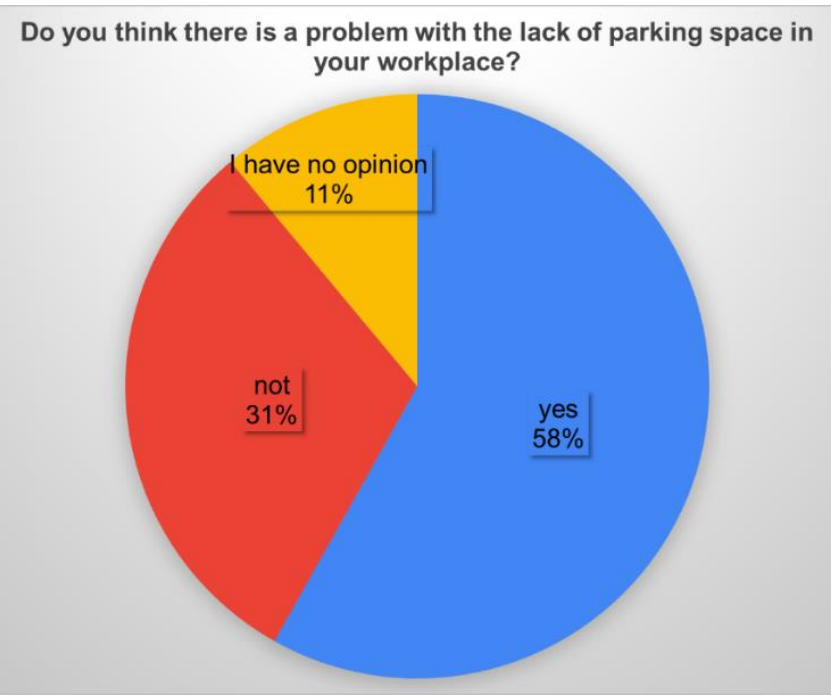

Fig. 8 Sufficiency of parking spaces at the workplace

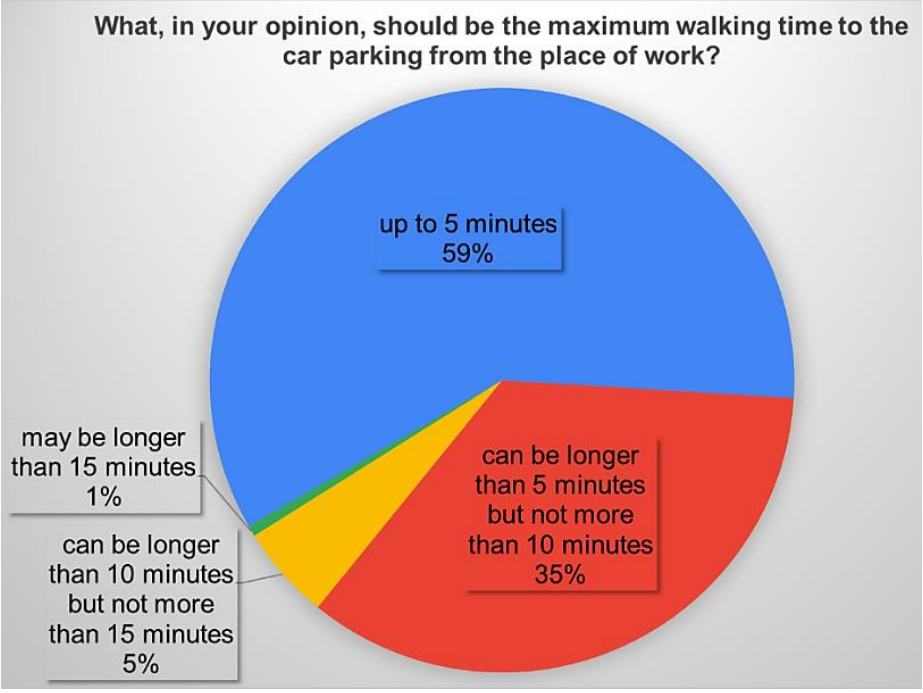

Fig. 9 Respondents' acceptable distance between the car park and the workplace 


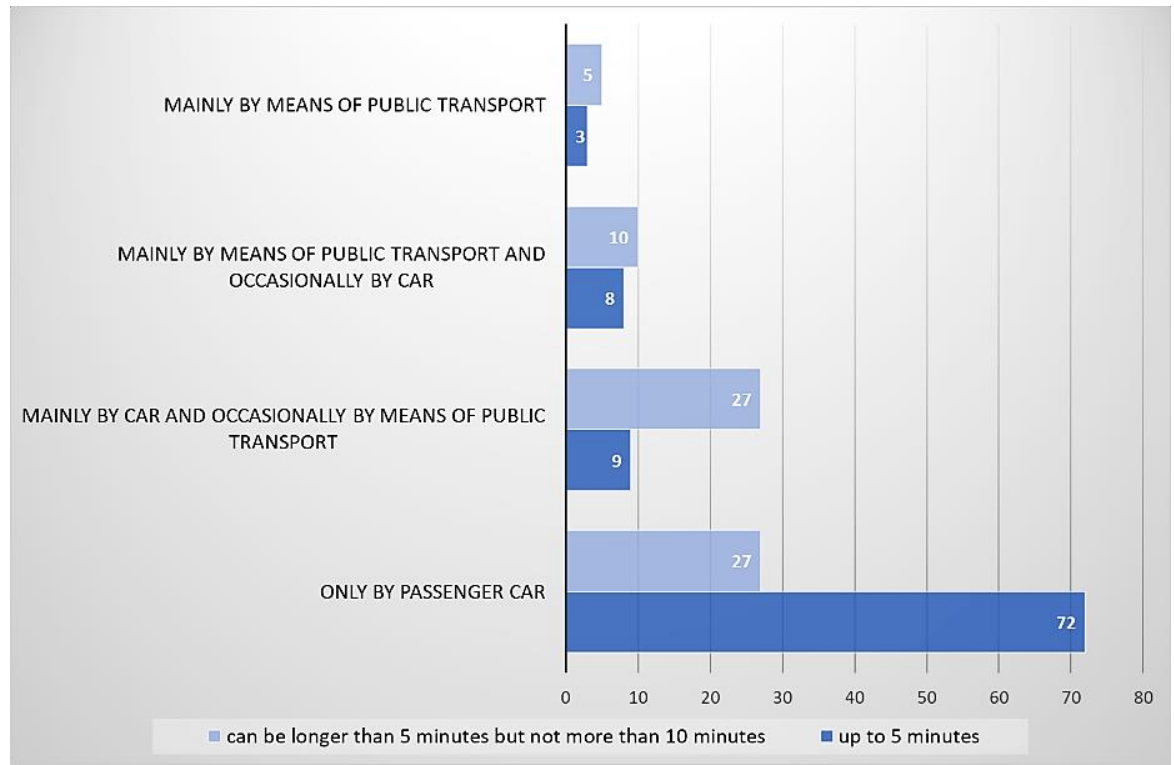

Fig. 10 Acceptable distance of the car park from the workplace according to people declaring different means of transport during their commute (number of people who answered the question "What do you think should be the maximum walking time to the car park from the workplace?")

$88 \%$ of respondents positively evaluate the use of vertical parking (answer "yes" or "rather yes") (Fig. 11).

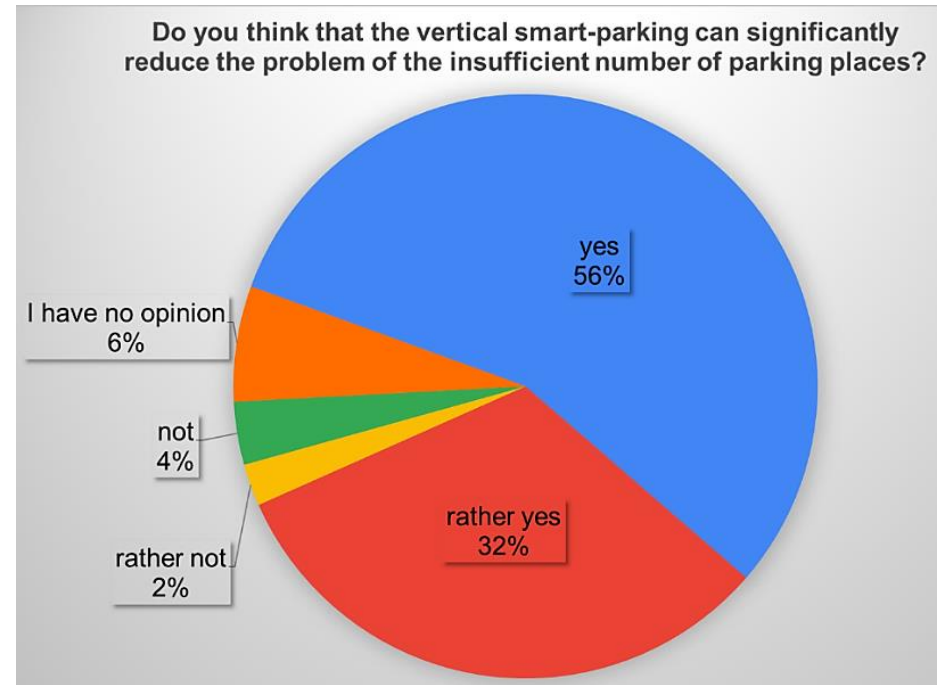

Fig. 11 Evaluation of a smart parking solution to increase parking space

The evaluation of four types of car parks -surface car park, underground car park, multi-storey car park and smart car park - in terms of safety and comfort is shown in Fig. 12. Smart vertical parking is considered as the best (53\%). Surface parking is the worst rated, with $18 \%$ of respondents having a poor perception of its safety and comfort features. 


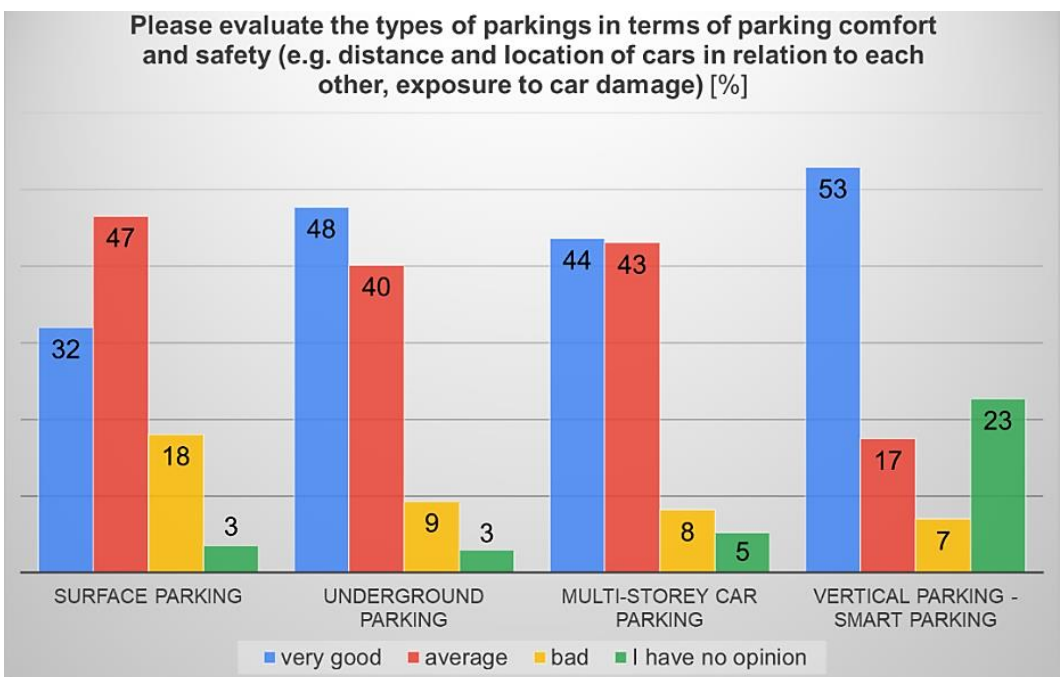

Fig. 12 Evaluation of specific types of car parks in terms of safety and comfort

An assessment of four types of car parks - surface car park, underground car park, multi-storey car park and smart car park - in terms of aesthetics is shown in Fig. 13. The underground car park was rated best $(53 \%$ of respondents rated its aesthetics as very good). The surface car park was rated the worst. 19\% of respondents do not have an opinion on smart parking.

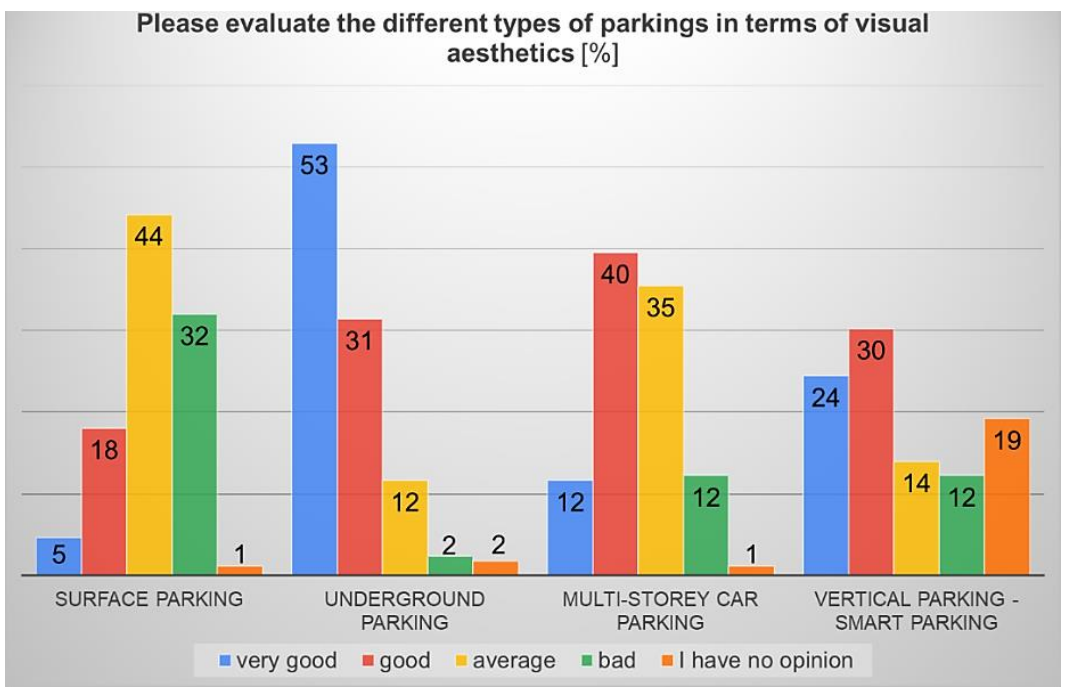

Fig. 13 Assessment of specific types of car parks in terms of aesthetics

The biggest problems perceived by users of surface car parks (Fig. 14) are the lack of sufficient parking spaces (58\% definitely yes and $28 \%$ yes), long time to find a parking space ( $48 \%$ definitely yes and $38 \%$ yes), high parking prices (38\% definitely yes and $31 \%$ yes), air pollution caused by the consumption of fuel while searching for a parking space (33\% definitely yes and $35 \%$ yes), and too large distances between the car parks and public transport stops (28\% definitely yes and $27 \%$ yes). Noise problems associated with car park use are seen as the least important ( $41 \%$ no and $22 \%$ definitely no). A relatively high proportion of respondents $(39 \%)$ do not perceive the condition of car park surface to be poor. 


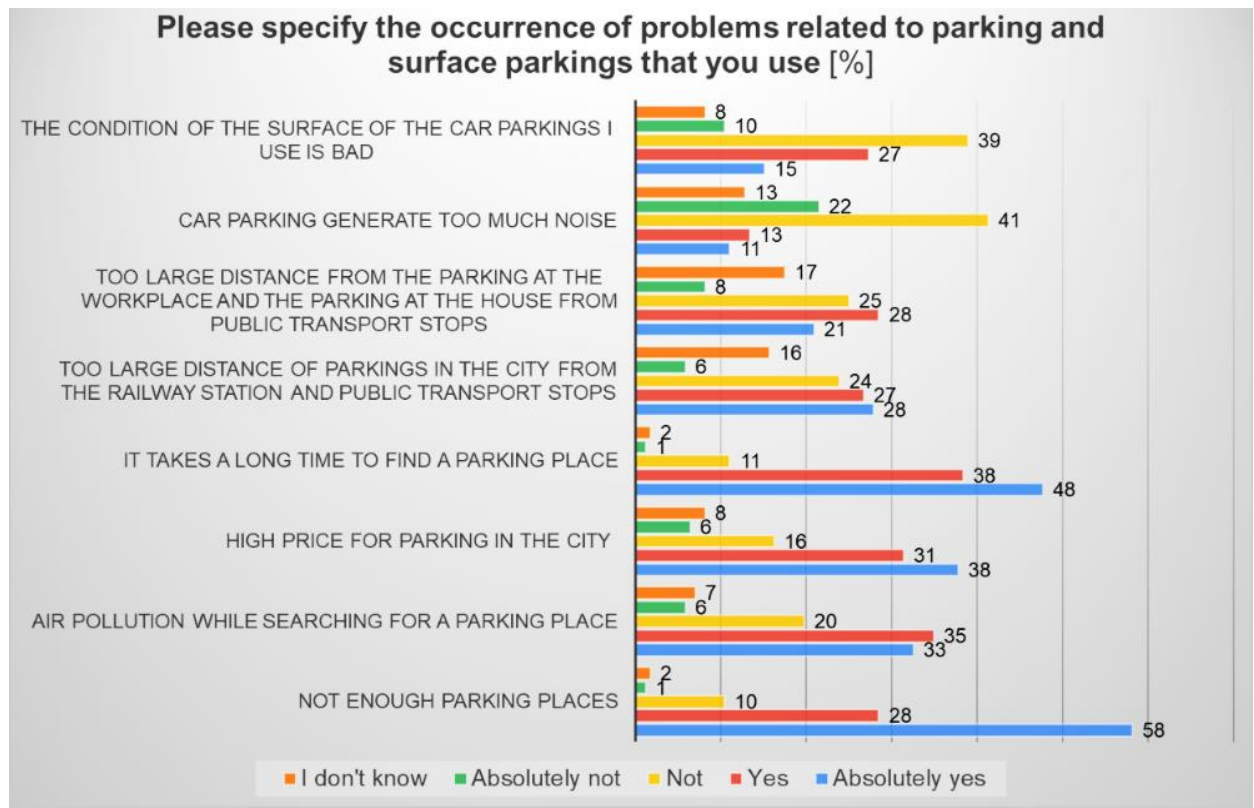

Fig. 14 Problems associated with parking and use of surface car parks

According to respondents, three factors should be taken into account when planning new car parks in the city: it is important to reduce the time spent looking for a free parking space (104 votes); it is important to use solutions that allow more vehicles to be parked in a smaller space ( 90 votes); and it is important to ensure that the environmental impact of the project is as low as possible during construction and use (83 votes) (Fig. 15).

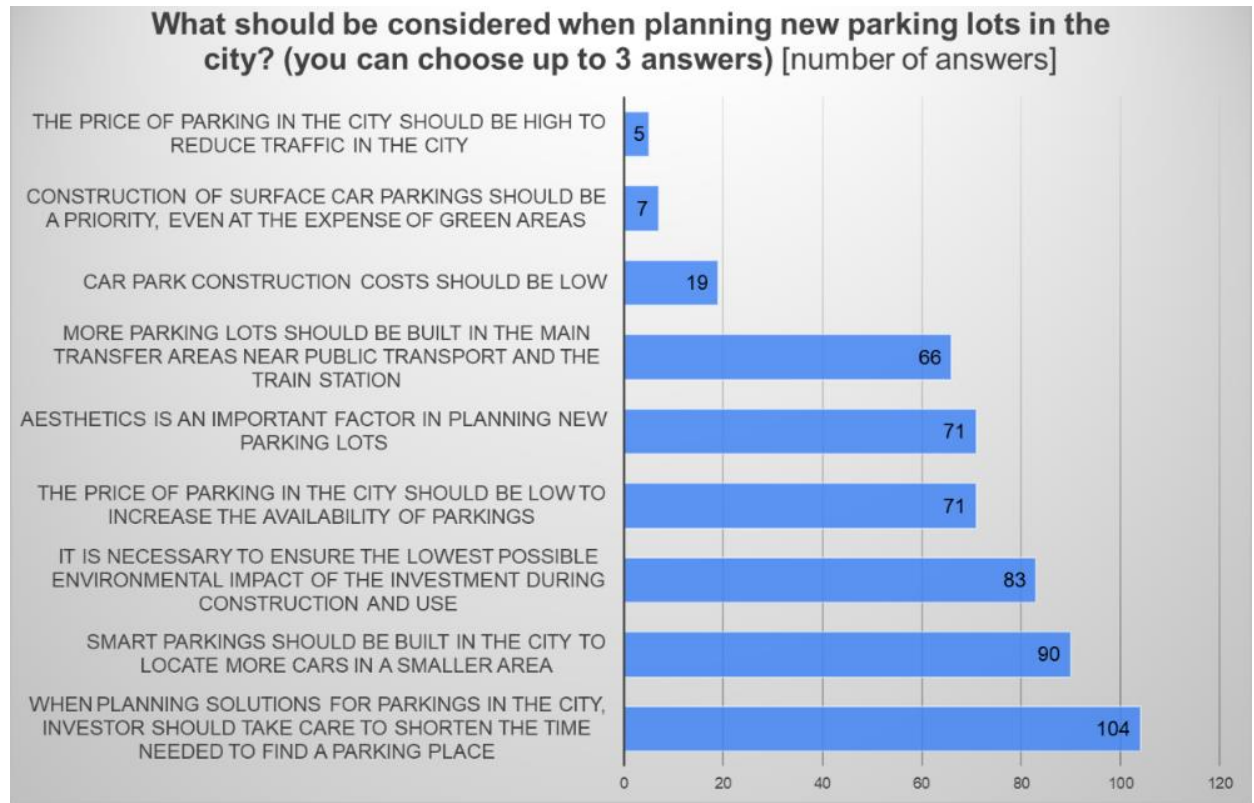

Fig. 15 Assessment of the need to take the indicated aspects into account in the planning and design of new car parks

This is followed by increasing the accessibility of car parks by setting a low cost for parking and taking into account the aesthetic side of parking solutions (71\%), 
and increasing the fluidity of transfers between different modes of transport by building car parks near transfer points (66\%).

\section{DISCUSSION OF THE RESULTS}

In the first part of the survey, respondents confirm the existence of problems that are identified in the literature (Cruz et al., 2017; Idris et al., 2009; Jog et al., 2015; Poliak et al., 2020; Wiśnicki and Dzhuguryan, 2019; Ivić et al., 2020). This mainly concerns the insufficient number of parking spaces, especially according to people living in multi-apartment buildings and commuting by car. Considering the development of the housing market in Poland and Silesia (Budownictwo mieszkaniowe, Raport, 2020), this problem will grow. A shortage of parking spaces entails longer search times, higher fuel consumption and consequently more pollution. The study included vertical parking, so-called smart parking, which is a relatively new solution to achieve space savings and reduce social and environmental impacts. Respondents in the questionnaire survey positively evaluate the use of the smart car park in terms of safety and comfort. They also point to the need to implement solutions that save parking space and reduce the environmental impact of the parking process.

Public opinion surveys before planning and design of car parks help to determine the conditions under which investments are made to serve the whole community. They also make it possible to reduce the efforts and costs of wrong decisions. In particular, they are a valuable resource in the process of ecodesign and green and sustainable public procurement.

Fig. 16 shows a preliminary comparison of selected parameters for surface parking and smart parking.

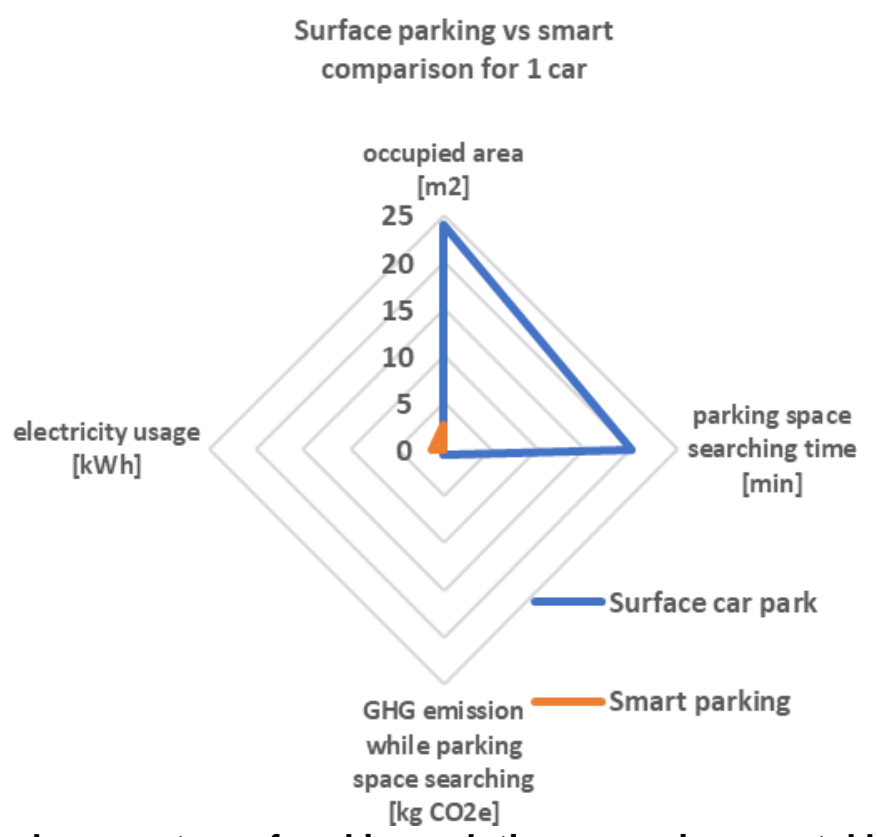

Fig. 16 Selected parameters of parking solutions - environmental benchmarking Source: own study 
This figure confirms the intuition of the questionnaire survey respondents. Smart parking takes up less space, is associated with reduced time searching for a parking space and lower greenhouse gas emissions into the atmosphere. It is also characterised by higher electricity consumption during use. A full comparison of parking solutions should cover the whole life cycle. Such an analysis can be carried out using life cycle assessment LCA. Hence, a continuation of the research issue is needed.

\section{CONCLUSIONS}

Difficulties in finding a place to park, environmental pollution due to increased fuel consumption when searching for a parking space, the increasing number of cars in urban areas and the development of the housing market are examples of factors that lead to a change in investment objectives with regard to parking design. This article presents the results of a questionnaire survey, which shows how important environmental and organisational aspects are becoming in the public consciousness in the context of interchange planning. It also presents directions for further research which should support the eco-design process.

\section{ACKNOWLEDGEMENTS}

This paper was financed from the resources of the Silesian University of Technology, project no. 6: 31/010/SDU20/0006, subproject no. 31/010/SDU20/0006-10.

\section{REFERENCES}

Budownictwo mieszkaniowe w województwie śląskim w 2019 r., Raport Urzędu Statystycznego w Katowicach, 22.07.2020 r.

Bukowski A., Nóżka M. \& Smagacz-Poziemska M. (2018). How do parking practices structure urban territorial communities?, Urban Development Issues, vol. 59, pp. 5-16. DOI: 10.2478/udi-2018-0024

Cruz L., Barata E., Ferreira J.P., Freire F. (2017). Greening transportation and parking at University of Coimbra, International Journal of Sustainability in Higher Education Vol. 18 No. 1, pp. 23-38. DOI: 10.1108/IJSHE-04-2015-0069.

Ferretti, V., (2016). From stakeholders analysis to cognitive mapping and Multi-Attribute Value Theory: An integrated approach for policy support. European Journal of Operational Research 253(2), pp. 524-541. Available at: https://dx.doi.org/10.1016/j.ejor.2016.02.054.

Górniak, J. (2016). Znaczenie logistyki miejskiej w wybranych miastach europejskich. Analiza porównawcza. Zeszyty Naukowe Politechniki Częstochowskiej Zarządzanie 24(1). pp. 140-151.

Idris M.Y.I., Leng Y. Y., Tamil E.M., Noor N.M. and Razak Z. (2009), Car Park System: A Review of Smart Parking System and its Technology, Information Technology Journal 8 (2), pp.101-113.

Ivić M., Kilić J., Rogulj K., \& Jajac N. (2020). Decision Support to Sustainable Parking Management-Investment Planning through Parking Fines to Improve Pedestrian Flows. Sustainability 12(22): 9485.

Jog Y., Sajeev A., Vidwans S., Mallick C. (2015). Understanding Smart and Automated Parking Technology. International Journal of $u$ - and e-Service, Science and Technology 8, pp. 251-262. DOI:10.14257/ijunesst.2015.8.2.25. 
Mathew, S.S., Atif, Y., Sheng, Q.Z., \& Maamar, Z. (2014). Building sustainable parking lots with the Web of Things. Personal and Ubiquitous Computing 18(4): pp. 895907. Available at: https://dx.doi.org/10.1007/s00779-013-0694-7.

Poliak, M., Poliaková, A., \& Culík, K., (2020). Impact of the Social Law on Truck Parking Sustainability in the EU. Sustainability 12(22): 9430.

Ślęzok M., Łuczak K. (2015), Intelligent building, automated car parking system, Zeszyty Naukowe Politechniki Śląskiej. Seria Organizacja i Zarządzanie z. 77/2015, str. 217-226.

Kurczewski P., Lewandowska A., eds, (2008) Zasady pro środowiskowego projektowania obiektów technicznych dla potrzeb zarządzania ich cyklem życia. Wyd. KMB DRUK, Parkowo.

Wiśnicki B. and Dzhuguryan T. (2019). Integrated sustainable freight transport system for city multi-floor manufacturing clusters, Multidisciplinary Aspects of Production Engineering, vol.2, no.1, pp.151-160. https://doi.org/10.2478/mape-2019-0015.

\begin{abstract}
The aim of the article is to identify problems and public expectations regarding parking and the application of different parking solutions. Based on the results of a CAWI questionnaire survey, an evaluation of selected parking solutions is presented. Among others, vertical parking has been taken into account, the use of which is associated with a reduction in the area required for parking and an improvement in environmental performance characteristics at the use stage. This study is part of the search for sustainable solutions in city logistics. The results of the study serve as an initial insight into the opinions of one group of users in the life cycle of a car park. They can be used as an introduction to the eco-design of parking solutions and to compare different parking systems. The study was carried out as part of a project entitled: "Analysis of the environmental impact of a vertical parking solution using life cycle assessment at the design stage" carried out at the Silesian University of Technology.
\end{abstract}

Keywords: parking, sustainable development, questionnaire, smart city, transport 